\title{
Relation Between Quality of Life of Mothers of Children With Cerebral Palsy and the Children's Motor Functioning, After Ten Months of Rehabilitation
}

\author{
Cejane Oliveira Martins Prudente \\ Maria Alves Barbosa ${ }^{2}$ \\ Celmo Celeno Porto ${ }^{3}$
}

\begin{abstract}
This study aims to analyze the quality of life of mothers of children with cerebral palsy, correlated with the evolution of their children's gross motor function after ten months of rehabilitation. An observational, longitudinal study was carried out in Goiânia, Goiás, Brazil, involving 100 mothers and children with cerebral palsy. The children's motor function was evaluated using the Gross Motor Function Measure (GMFM) and the mothers' quality of life using the Medical Outcomes Study 36-item Short Form Health Survey (SF-36). After ten months of rehabilitation, the children's gross motor function had significantly improved $(p<0.001)$, while the mothers only presented a significant improvement $(p<0.001)$ in the bodily pain domain. The improvement in the motor function of children with cerebral palsy did not influence the changes in the mothers' quality of life.
\end{abstract}

Descriptors: Quality of Life; Mothers; Caregivers; Cerebral Palsy; Rehabilitation.

\footnotetext{
${ }^{1}$ Physical Therapist, Doctoral Student in Health Sciences. Faculty, Universidade Católica de Goiás, GO, Brazil. E-mail: cejanemp@ hotmail.com.

${ }^{2}$ RN, Ph.D. in Nursing, Faculty, Universidade Federal de Goiás, GO, Brazil. E-mail: maria.malves@gmail.com.

${ }^{3}$ Physician, Ph.D. in Medicine, Coordinator, Health Sciences Graduate Program, Universidade Federal de Goiás, GO, Brazil. E-mail: celmo@medicina.ufg.br.
}

Corresponding Author:

Cejane Oliveira Martins Prudente

Departamento de Enfermagem. Pontifícia Universidade Católica de Goiás

Praça Universitária, 1440, área 4

Setor Universitário

CEP: 74605-010 Goiânia, Goiás, Brasil

E-mail: cejanemp@hotmail.com 


\section{Relação entre a qualidade de vida de mães de crianças com paralisia cerebral e a função motora dos fillhos, após dez meses de reabilitação}

O objetivo deste estudo foi analisar a qualidade de vida de mães de crianças com paralisia cerebral, correlacionando-a com a evolução da função motora grossa das crianças, após dez meses de reabilitação. Trata-se de estudo observacional, longitudinal, realizado em Goiânia, Goiás, Brasil, com 100 mães e seus filhos com paralisia cerebral. A função motora das crianças foi avaliada pela Medição da Função Motora Grossa (GMFM) e a qualidade de vida das mães pelo Medical Outcomes Study 36-item Short Form Health Survey (SF-36). Após dez meses de reabilitação, as crianças obtiveram melhora significativa $(p<0,001)$ na função motora grossa e as mães apresentaram melhora significativa $(p<0,001)$ apenas no domínio dor. A melhora da função motora grossa das crianças com paralisia cerebral não influenciou as mudanças ocorridas na qualidade de vida das mães.

Descritores: Qualidade de Vida; Mães; Cuidadores; Paralisia Cerebral; Reabilitação.

\section{Relación entre la calidad de vida de madres de niños con parálisis cerebral y la función motora de los niños, después de diez meses de rehabilitación}

El objetivo de este estudio fue analizar la calidad de vida de las madres de niños con parálisis cerebral, correlacionándola con la evolución de la función motora gruesa de los niños, después de diez meses de rehabilitación. Se trata de un estudio de observación, longitudinal, realizado en la ciudad de Goiania, estado de Goiás, en Brasil, con 100 madres y sus hijos con parálisis cerebral. La función motora de los niños fue evaluada por la Medición de la Función Motora Gruesa (GMFM) y la calidad de vida de las madres por el Medical Outcomes Study 36-item Short Form Health Survey (SF-36). Después de diez meses de rehabilitación, los niños obtuvieron una mejoría significativa $(p<0,001)$ en la función motora y las madres presentaron una mejoría significativa $(p<0,001)$ apenas en el dominio dolor. La mejoría de la función motora gruesa de los niños con Parálisis Cerebral no influyó en los cambios ocurridos en la calidad de vida de las madres.

Descriptores: Calidad de Vida; Madres; Cuidadores; Parálisis Cerebral; Rehabilitación.

\section{Introduction}

Cerebral palsy is a complex clinical entity, with high incidence levels, a range of severity levels and several complications, often needing special care. Changes occur in family routines, with a possible direct impact on caregivers' lives, mainly mothers.

Conceptualizing cerebral palsy has always been a challenge, and countless attempts have been made. In 2007, considering its complexity, the following concept was expressed: "Cerebral Palsy describes a group of permanent disorders of the development of movement and posture, causing activity limitation, that are attributed to nonprogressive disturbances that occurred in the developing fetal or infant brain. The motor disorders of cerebral palsy are often accompanied by disturbances of sensation, perception, cognition, communication, and behavior, by epilepsy, and by secondary musculoskeletal problems"(1).

Another aspect that cannot be ignored is the impact of cerebral palsy on the family's internal dynamics, due to the fact that its members are confronted with a different reality that demands new functions. These sudden changes generate conflicts and sudden changes in routines, generally putting the greatest overload on the mother ${ }^{(2)}$. The way parents adjust is crucial for the future well being of the child and the entire family(3). 
Each family is unique and will process this experience in different ways. Many families are strengthened and the disabled child serves as a uniting factor. In others, the situation leads to family rupture ${ }^{(4)}$. The care delivered to a family member with a chronic disease can result in feelings of overload or tension and even reduce the caregiver's quality of life(5).

In 1994, in order to systemize quality of life research, the World Health Organization proposed the following definition: "an individual's perception of their position in life in the context of the culture and value systems in which they live and in relation to their goals, expectations, standards and concerns"(6). The quality of life concept is marked by subjectivity, involving all core components of the human condition, whether physical, psychological, social, cultural or spiritual(7).

In this age of transition from the biomedical health model to a new holistic and generalist paradigm, aimed at understanding patients and how the disease affects the family context, profound knowledge is needed on all biopsychosocial aspects families are inserted in. Through more contextualized interventions, better quality care can be delivered to family members.

There is a noticeable lack of research on the quality of life of mothers of children with cerebral palsy. Existing studies are mostly cross-sectional, using small samples, without homogeneous distribution according to the child's motor commitment levels; this information is important for professionals who are part of this process. With better knowledge on all aspects of these mothers' lives, health professionals can act not only on the child's physical commitment, but also on the entire family routine, mainly on the mother's life, who is most involved in the care process.

This research aimed to analyze the quality of life of mothers of children with cerebral palsy, correlating it with the evolution of the children's gross motor function after ten months of rehabilitation.

\section{Methods}

The quantitative methodological approach was adopted to develop this observational and longitudinal research, carried out between August 2007 and July 2008. The project received approval from the Research Ethics Committee at Universidade Católica de Goiás, under n.1235.0.000.168-07 and the study complied with the ethical recommendations of Resolution No 196/96 by the National Health Council/Ministry of Health, which rules on research involving human beings ${ }^{(8)}$.

\section{Participants}

At first, 146 mothers of children with cerebral palsy participated, together with their children, who received care at the physiotherapy sector of three institutions in Goiânia, Goiás, Brazil: Unidade Renascer da Associação Pestalozzi, Centro de Orientação, Reabilitação e Assistência ao Encefalopata (CORAE) and Centro de Reabilitação e Readaptação Dr. Henrique Santillo (CRER). Mothers of children between 3 and 13 years of age were included, within the five levels of the Gross Motor Function Classification System (GMFCS) for cerebral palsy.

Only 100 of the 146 mothers of children with cerebral palsy who started the study completed ten months of observation. This was due to different reasons, including the child's death, transfer to another institution, discharge due to frequent absence and the mother's waiver to continue treatment.

\section{Instruments}

The motor commitment level of the children with cerebral palsy was based on the GMFCS and the gross motor function was assessed using the Gross Motor Function Measurement (GMFM-88). To analyze the mothers' quality of life, the Medical Outcomes Study 36item Short Form Health Survey (SF-36) questionnaire was applied.

The GMFCS assesses the severity of the movement disorder in children with cerebral palsy ${ }^{(9)}$. This classification permits measuring skills and limitations, emphasizing sitting and walking functions, ranking cerebral palsy in five levels ${ }^{(10)}$, with I as the lightest and $\mathrm{V}$ as the most severe level.

The GMFM measures changes in the gross motor function in quantitative terms ${ }^{(11)}$. This instrument has been widely used for clinical measurements and in scientific research, with demonstrated reliability. The test assesses the motor function in five dimensions: (1) lying and rolling; (2) sitting; (3) crawling and kneeling; (4) standing and (5) walking, running and jumping.

The Medical Outcome Study 36-item Short-Form Health Survey (SF-36) is one of the most widely used generic quality of life assessment questionnaires. It has been translated and adapted for use with Brazilian populations ${ }^{(12)}$. It is succinct but comprehensive, easily applicable and understandable and includes 36 items, distributed in 8 domains - functional capacity, physical conditions, pain, general health status, vitality, social conditions, emotional conditions and mental health. The 
questionnaire produces eight scores ranging from 0 to 100 , with zero corresponding to the worst and 100 to the best health status.

\section{Procedures}

The mothers and children were selected according to the abovementioned inclusion and exclusion criteria. The GMFCS was applied to define the severity level of the movement disorder in these children with cerebral palsy.

The mothers agreed to participate in the research in writing, after reading the free and informed consent term that offered information about the research. The instruments (GMFM-88 and SF-36) were initially applied in August and September 2007 and again after ten months of rehabilitation, finishing in June and July 2008, before the children went on leave for holidays. The researchers decided to finish the research in this period so as to avoid that holidays would influence the mothers' quality of life and the children's gross motor function.

During this ten-month period, all children participated in the rehabilitation process, accompanied by different professionals, according to each child's needs, including a physiotherapist; occupational therapist; speech, language and hearing scientist; social worker; psychologist, musical therapist, nurse and physicians from different specialties. With regard to physiotherapy, different approaches were used as needed, such as the Bobath neuroevolutive concept, hydrotherapy, and equotherapy, among others. Some children were subject to surgical interventions, application of botulinic toxin and phenol, among other procedures.

Six previously trained evaluators applied all instruments. The SF-36 was applied in an interview with the mothers. Out of 100 participants, only four selfapplied the questionnaires.

\section{Statistical analysis}

Statistical Package for the Social Science (SPSS) software for Windows (version 15.0) was used for data analysis. To compare results of the first and last assessments of the children's motor function and SF-36 domains, the Wilcoxon test was used, as the obtained data did not have a normal distribution. To relate the changes in each SF-36 domain with the evolution in the motor function of the children with cerebral palsy, during the ten-month interval, linear regression analysis was used. This statistical technique was chosen because the variables involve different measures. In this analysis, both relative and absolute improvements in quality of life and motor function were used. As the results were similar, only the relative improvement was shown as a table. In all analyses, significance was set at $5 \%$.

\section{Results}

With regard to the GMFCS level, the 100 children were distributed as follows: 19 level I, 17 level II, 20 level III, 20 level IV and 24 level V. From a clinical and anatomic commitment perspective, 16 children had spastic hemiplegia, 1 ataxic hemiplegia, 34 spastic diplegia, 1 ataxic diplegia, 2 athetoid diplegia, 27 spastic quadriplegia, 2 ataxic quadriplegia, 16 athetoid quadriplegia and 1 hypotonic quadriplegia.

The children's age ranged from 3.7 to 13 years, averaging at 7.53 years. Fifty-eight children were male. Out of 100 mothers who participated in the research, only 7 were foster mothers, and their ages ranged from 19.5 to 61.1 years, averaging at 33.36 years.

Table 1 shows a statistically significant improvement $(p<0.001)$ in the gross motor function of the children with cerebral palsy assessed by the GMFM-88, after ten months of rehabilitation. The absolute improvement in the motor function was $2.06 \%$, while the relative improvement corresponded to $13.02 \%$.

Table 1 - Evolution of children's gross motor function after ten months of rehabilitation. Goiânia, 2007-2008

\begin{tabular}{ccccc}
\hline GMFM-88 & $\mathbf{n}$ & Average (\%) & Standard deviation & $\mathbf{p}$ \\
\hline $1^{\text {st }}$ assessment & 100 & 53.08 & 34 & $<0.001$ \\
Last assessment & 100 & 55.14 & 34.20 & \\
\hline
\end{tabular}

Test: Wilcoxon.

As observed in Table 2, which compared the results of the quality of life questionnaire SF-36 between the first and final assessment, after ten months of rehabilitation, the mothers of children with cerebral palsy presented a statistically significant difference for the pain domain only, improving by $14.57(p<0.001)$. No statistically significant differences were found for functional capacity, physical conditions, emotional conditions, social conditions, general health status, vitality and mental health, on the other hand. It should be highlighted, however, that the average score on all domains exceeded 50 on the first assessment, and that the lowest scores were found for pain and vitality, with a statistically significant improvement on the final assessment exactly in the pain domain. 
Table 2 - Score on each SF-36 domain, comparing the first and final assessments, after ten months of rehabilitation. Goiânia, 2007-2008

\begin{tabular}{ccccc}
\hline Domain & $\mathbf{n}$ & Average* $^{*}$ & $\begin{array}{c}\text { Standard } \\
\text { deviation }\end{array}$ & $\mathbf{p}$ \\
\hline $\begin{array}{c}\text { Functional capacity } \\
1^{\text {st }} \text { assessment }\end{array}$ & 100 & 82.65 & 15.87 & 0.289 \\
Last assessment & 100 & 79.60 & 21.45 & \\
Physical conditions & & & & 0.567 \\
$1^{\text {st }}$ assessment & 100 & 65.75 & 34.93 & \\
Last assessment & 100 & 68.25 & 40.02 & \\
Emotional conditions & & & & 0.479 \\
$1^{\text {st }}$ assessment & 100 & 62.67 & 38.29 & \\
Last assessment & 100 & 65.33 & 41.82 & \\
Pain & & & & \\
$1^{\text {st }}$ assessment & 100 & 54.66 & 27.55 & \\
Last assessment & 100 & 69.23 & 23.69 & \\
Social conditions & & & & \\
$1^{\text {st }}$ assessment & 100 & 73.13 & 23.86 & \\
Last assessment & 100 & 73.00 & 26.46 & \\
General health status & & & & 0.674 \\
$1^{\text {st }}$ assessment & 100 & 74.45 & 21.14 & \\
Last assessment $_{\text {Vitality }}$ & 100 & 76.15 & 19.84 & \\
$1^{\text {st }}$ assessment & 100 & 56.50 & 22.50 & \\
Last assessment $_{\text {Mental health }}$ & 100 & 58.40 & 18.97 & \\
$1^{\text {st }}$ assessment & 100 & 65.16 & 20.25 & \\
Last assessment & 100 & 65.12 & 19.88 & \\
\hline & & & & \\
\hline
\end{tabular}

Test: Wilcoxon. * Raw-scale.

When correlating the identified changes in each domain of the quality of life questionnaire SF-36 with the evolution in the gross motor function of children with cerebral palsy after ten months, no significant relation was observed in any of the domains, that is, the improvement in these children's gross motor function, although significant, did not influence the improvement in the pain domain of their mothers' quality of life (Table 3 ).

Table 3 - Correlation between alterations on each SF-36 domain for mothers and children's evolution on GMFM88 after ten months of rehabilitation. Goiânia, 20072008

\begin{tabular}{lcc}
\hline \multicolumn{1}{c}{ Correlated variables* } & Angular coefficient & p \\
\hline Functional capacity & 0.103 & 0.161 \\
Physical conditions & -0.103 & 0.746 \\
Emotional conditions & 0.038 & 0.875 \\
Pain & 0.237 & 0.596 \\
Social conditions & 0.048 & 0.747 \\
General health status & -0.059 & 0.499 \\
Vitality & 0.012 & 0.957 \\
Mental health & 0.122 & 0.244 \\
\hline
\end{tabular}

Linear regression analysis. *relative indices.

\section{Discussion}

In literature, few studies were identified which assess the quality of life of mothers of children with cerebral palsy. The only longitudinal study found aimed to verify whether, after using botulinic toxin in children with cerebral palsy, the caregivers' quality of life improved ${ }^{(13)}$. That study is accompanied by strong limitations: the small number of caregivers (only 20) and the short time the sample was followed (only three months). The quality of life assessment instrument was the same used in the present research, but the results could be considered in disagreement with regard to the percentage improvements in each domain of the mothers' quality of life after three months, with $5 \%$ on functional capacity, $10 \%$ on physical conditions, $6 \%$ on pain, $9 \%$ on general health status, $8 \%$ on vitality, $8 \%$ on social conditions, $23 \%$ on emotional conditions and $12 \%$ on mental health. In statistical terms, however, the average improvement was not significant.

Two other studies on the quality of life of mothers of children with cerebral palsy were found in literature, which used the SF-36 questionnaire. Both were restricted to a cross-sectional design, however, without reassessment after the rehabilitation period ${ }^{(14}$ 15). These studies deserve further analysis due to their methodological quality and because they serve as a parameter for comparison with the data found in the initial assessment of mothers in this research.

The first study mentioned was carried out in Turkey and assessed the quality of life of 40 mothers of children with cerebral palsy, in comparison to 44 mothers of children with other kinds of problems, such as fever, cough or diarrhea. The SF-36 and GMFCS were used. The results showed that, except for functional capacity, the average score on the SF-36 domains was significantly lower in mothers of children with cerebral palsy when compared with the control group. Averages on all SF-36 domains for the mothers of children with cerebral palsy were higher than 50 and the highest score was for functional capacity, similar to the results of the initial assessment in this research. On the opposite, the lowest score in the Turkish research was for general health status ${ }^{(14)}$.

Another study, carried out in Turkey as well, investigated the quality of life of 40 primary caregivers of children with cerebral palsy in comparison to 40 primary caregivers of children without cerebral palsy. The SF-36 and GMFCS questionnaires were used. The level distribution of the children with cerebral palsy on 
the GMFCS was not homogeneous, with more children at levels I and V. Scores for functional capacity, vitality, general health status and emotional conditions were significantly lower among primary caregivers of children with cerebral palsy in comparison with the control group. Differently from the initial assessment in the present research, almost all SF-36 scores in the group of caregivers to children with cerebral palsy were lower, and less than 50 in four domains. The score in the pain domain, on the other hand, was higher than in the present research. Similarly, the highest score was for functional capacity ${ }^{(15)}$.

Research has reported functional improvements in children with cerebral palsy submitted to different approaches $^{(16)}$. After ten months of rehabilitation, the children with cerebral palsy accompanied in this research showed a statistically significant improvement in their gross motor function.

In this study, the evolution in the gross motor function of the children with cerebral palsy did not influence the changes in their mothers' quality of life. It should be highlighted, however, that no study was found in literature which assessed the mothers' quality of life after their children had gone through a long rehabilitation period. By the way, the only longitudinal study found on the quality of life of mothers whose children had cerebral palsy did not report on whether the children's motor function improved after botulinic toxin applications. Hence, no correlation was established with the caregivers' quality of life ${ }^{(13)}$.

With regard to the possible correlation between the quality of life of mothers whose children have cerebral palsy and the children's level of motor commitment, only three cross-sectional studies were found, with conflicting results ${ }^{(14-15,17)}$. Moreover, due to different goals and methods, the results cannot be correlated with the present research. Two studies observed that the child's degree of motor limitation did not interfere in the quality of life of mothers whose children had cerebral palsy ${ }^{(15,17)}$. Another study found a different result, as a significant correlation was found between the mothers' quality of life and the degree of the children's motor commitment in the physical conditions, vitality, emotional conditions and mental health domains ${ }^{(14)}$.

Due to the fact that quality of life is very complex, influenced by different factors, limitations are easily recognized in this research. Facts occurred during this ten-month rehabilitation period may have exerted a positive or negative influence on these mothers' lives, such as a surgical intervention in the child or the birth of another child for example.

\section{Final considerations}

After children with cerebral palsy had gone through ten months of rehabilitation, their mothers' quality of life had significantly improved in the pain domain only; the children with cerebral palsy significantly improved their gross motor function, and this improvement did not influence the changes in their mothers' quality of life, not even in the pain domain.

Care delivery involves not only the patient, but also the entire context, in which the caregiver figure emerges as a care instrument ${ }^{(18)}$. The analysis of the study data allows for the proposition of strategies directed at the true needs of these children's mothers, modifying current conducts used by rehabilitation professionals. The mothers' aspects of vitality and pain deserve special attention, as these obtained the lowest scores on the initial assessment.

This research does not make any claim on exhausting the theme. The goal was to analyze the impact of the evolution in the children's gross motor function on the mothers' quality of life, but the results found here indicate the need to examine other factors, such as the child's cognitive evolution.

\section{References}

1. Rosenbaum P, Paneth N, Leviton A, Goldstein M, Bax M, Damiano $D$, et al. A report: the definition and classification of cerebral palsy, april 2006. Dev Med Child Neurol 2007 February; 49:8-14.

2. Rizzo AMPP. Psicologia em Paralisia Cerebral: experiência no setor de psicologia infantil da AACD. In: Ferrareto I, Souza AMC. Paralisia Cerebral: aspectos práticos. $2^{a}$ ed. São Paulo (SP): Memnon; 2001. p. 297-317.

3. Bavin JTR. Os problemas dos pais. In: Finnie NA. O manuseio em casa da criança com Paralisia Cerebral. São Paulo (SP): Manole; 2000. p. 19-34.
4. Núñez B. La familia con un hijo con discapacidad: sus conflictos vinculares. Arch Argent Pediatr 2003; 101(2):133-42.

5. Sales E. Family burden and quality of life. Qual Life Res 2003; 12(Suppl 1):33-41.

6. Saxena S, Orley J. Quality of life assessment: the World Health Organization perspective. Eur Psychiatry 1997; 12(Suppl 3):263-6.

7. Martins LM, França APD, Kimura M. Qualidade de vida de pessoas com doença crônica. Rev Latino-am Enfermagem 1996 dezembro; 4(3):5-18. 
8. Conselho Nacional de Saúde (BR). Diretrizes e normas regulamentadoras de pesquisas envolvendo seres humanos. Resolução 196/96. Brasília (DF): Diário Oficial da União; 1996 p.21082-5.

9. Morris C, Bartlett D. Gross motor function classification system: impact and utility. Dev Med Child Neurol 2004; 46:60-5.

10. Palisano R, Rosenbaum P, Walter S, Russell D, Wood E, Galuppi B. Development and reliability of a system to classify gross motor function in children with cerebral palsy. Dev Med Child Neurol 1997; 39:214-23.

11. Russell DJ, Rosenbaum PL, Cadman DT, Gowland C, Hardy $\mathrm{S}$, Jarvis $\mathrm{S}$. The gross motor function measure: a means to evaluate the effects of physical therapy. Dev Med Child Neurol 1989; 31:341-52.

12. Ciconelli RM, Ferraz MB, Santos W, Meinão I, Quaresma MR. Tradução para a língua portuguesa e validação do questionário genérico de avaliação de qualidade de vida SF-36 (Brasil SF-36). Rev Bras Reumatol 1999 maio/junho; 39(3):143-50.

13. Bianchin MA, Altomani C, Chueire R. Qualidade de vida dos cuidadores de crianças portadoras de paralisia cerebral após aplicação de toxina botulínica. Med Reabil 2007 janeiro/abril; 26(1):20-4.

14. Eker $L$, Tüzün EH. An evaluation of quality of life of mothers of children with cerebral palsy. Disabil Rehabil 2004 Dec; 26(23):1354-9.

15. Tuna $H$, Ünalan $H$, Tuna $F$, Kokino S. Quality of life of primary caregivers of children with cerebral palsy: a controlled study with Short Form-36 questionnaire. Dev Med Child Neurol 2004; 46:646-8.

16. Tsorlakis N, Evaggelinou C, Grouios G, Tsorbatzoudis C. Effect of intensive neurodevelopmental treatment in gross motor function of children with cerebral palsy. Dev Med Child Neuro 2004 Nov; 46(11):740-5.

17. Ones K, Yilmaz E, Cetinkaya B, Caglar N. Assessment of the quality of life of mothers of children with cerebral palsy (primary caregivers). Neurorehabil Neural Repair 2005 Sep; 19(3):232-7.

18. Souza LM, Wegner W, Gorini MIPC. Educação em saúde: uma estratégia de cuidado ao cuidador leigo. Rev Latino-am Enfermagem 2007 março/abril; 15(2):337-43. 